\section{Going along for the ride}

THE visit of Squadron-Leader Rakesh Sharma to the Salyut-7 space station has been widely acclaimed in the Soviet media as marking a new phase in the programme of "international" flights; for the first time the visitor came from a non-aligned country, India. (Apart from the Frenchman Jean-Loup Chrétien, all guest cosmonauts have hitherto come from the Comecon bloc.) Public reaction in India has been predictably euphoric. The

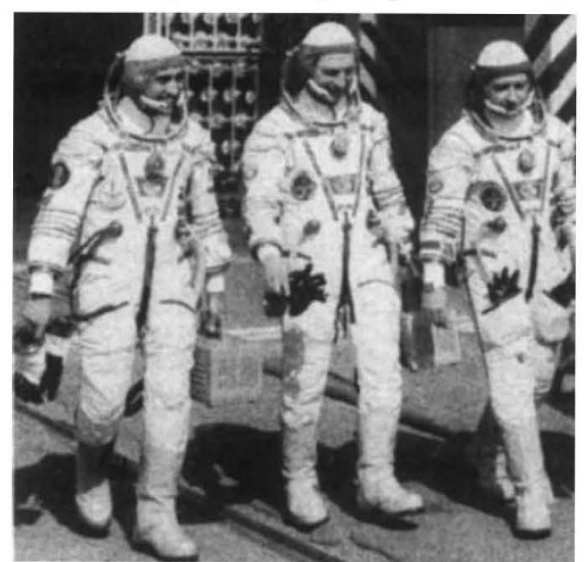

Indian cosmonaut Rakesh Sharma (left) joins Soviet cosmonauts Yuri Malyshev (centre) and Gennady Strekalov.

political importance of the event was highlighted by Sharma's conversation from space with the Indian Prime Minister, Mrs Indira Gandhi, in which he skilfully quoted the national poet Iqbal to imply that, from space, India looks "the best in all the world".

In the long term, however, the relevance of the mission to India's own space programme is problematic. For India's space effort rests firmly on the two "legs" of remote sensing and telecommunications, and aims at eliminating its dependence on foreign hardware as rapidly as possible. Media claims that the flight proves that India is a "technologically advanced" nation seem somewhat illogical. The launch of the indigenous Rohini satellite or the SRV launch vehicle can rightly be cited to substantiate such a claim. Guest cosmonauts to Salyut stations in the past, however, have included representatives of Mongolia, Vietnam and Cuba, which cannot yet claim an "advanced" level of technology.

The mission's greatest relevance to the routine Indian space programme lay in the "Terra" high resolution photographic survey of the Indian subcontinent, including the Andaman and Nicobar Islands (where it was hoped to find indications of oil, gas and mineral deposits) and of remote areas of the Himalayas and Karakoram.

The materials science experiments, on the other hand, although said to be "dictated by the needs of the Indian economy", centred on a standard feature

\section{Biotechnology}

of previous joint missions, the production of alloys difficult or impossible to obtain under normal gravity.

The most "Indian" note, from the Soviet point of view, was provided by the medical programme, which included yoga exercises performed by Sharma and which, it was hoped, might provide a means of alleviating the adverse effects of weightlessness on the locomotor system. (Moscow Radio was careful to point out that Sharma is not a yogi but an "ordinary person", since Soviet ideology tends to be wary of the philosophical aspects of yoga.) India also provided a portable "vector cardiograph" for monitoring the bioelectric activity of the heart at rest and under gradually increasing physical loads. The Indian medical team also resumed a line of research studied by the joint PolishSoviet mission of June 1978: the physiological and psychological changes in conditions of weightlessness. Since India has no regular space medicine programme, and since no country has so far been invited to send a second cosmonaut to the Salyut station, the results of these experiments, although helpful to spacefarers in general, are unlikely to benefit India directly.

Vera Rich

\title{
Low risks at a premium
}

THE Sun Alliance insurance group and Reed Stenhouse UK Ltd are planning to launch "Biotech Protection" - claimed to be the first insurance package geared specifically to the needs of biotechnology laboratories. The policy includes all-risks cover on assets and earnings against crossinfection of cultures, contamination of premises and seizure or closure of premises by safety authorities. Legal liabilities to. third parties for environmental pollution and innocent or fraudulent breach of confidential information can also be insured.

According to Reed Stenhouse, market research has shown that many biotechnology laboratories are not adequately insured against the risks peculiar to their work. Celltech Ltd, the UK biotechnology company, refuses even to discuss its insurance protection. Others in the industry are surprised that seizure by civil authorities is an insurable risk. And there is some scepticism about whether the risk of breach of confidential information could be assessed or a claim proved.

Mr Ken Davis of Reed Stenhouse is undeterred by such questions. His company will provide full advice to its clients on safety and security issues, he says, and the company's "loss engineers" will be able to assess the value of cell lines and evaluate dangerous practices. He denies that cover for disclosure of confidential information will encourage greater secrecy, because most companies already have good arrangements with their staff on such matters. But if the loss engineers were dissatisfied then they would be able to make appropriate recommendations. The package will be launched at the Biotech Europe exhibition, to be held in London during May.

Tim Beardsley

\section{Nature index of biotechnology stocks}

\begin{tabular}{|c|c|c|c|c|c|}
\hline $\begin{array}{l}\text { 12-Month } \\
\text { high }\end{array}$ & $\begin{array}{l}\text { 12-Month } \\
\text { low }\end{array}$ & Company & $\begin{array}{l}\text { Close } \\
\text { previous } \\
\text { month }\end{array}$ & $\begin{array}{l}\text { Close } \\
\mathbf{3 0} \text { Mar. }\end{array}$ & Change \\
\hline 14 & $101 / 2$ & Biogen (Switzerland) & 13 & 13 & $\mathbf{0}$ \\
\hline 2 & $1^{3 / 8}$ & Bio-Logicals (Canada) & $11 / 2$ & $13 / 8$ & $+1 / 8$ \\
\hline $14^{3 / 8}$ & $10^{1 / 8}$ & Bio-Response (USA) & $103 / 4$ & 11 & $+1 / 4$ \\
\hline 14 & $101 / 4$ & Cetus (USA) & $11 \frac{1}{4}$ & $121 / 8$ & $+7 / 8$ \\
\hline $10^{3} / 8$ & $6^{1 / 8}$ & Collaborative Research (USA) & $7 \%$ & $81 / 8$ & $+1 / 2$ \\
\hline $19^{7} / 8$ & $143 / 4$ & Damon (USA) & $171 / 2$ & $18^{1 / 8}$ & $+3 / 8$ \\
\hline $261 / 4$ & 13 & Enzo-Biochem (USA) & $163 / 4$ & $171 / 2$ & $+3 / 4$ \\
\hline $10 \frac{1}{8}$ & $63 / 4$ & Flow General (USA) & $73 / 4$ & $73 / 8$ & $-3 / 8$ \\
\hline $421 / 4$ & $311 / 4$ & Genentech (USA) & $331 / 2$ & 36 & $+3 \frac{1}{2}$ \\
\hline $103 / 4$ & 6 & Genetic Systems (USA) & $67 / 8$ & $61 / 2$ & $-3 / 8$ \\
\hline $171 / 4$ & $12 \frac{3}{8}$ & Genex (USA) & 13 & $131 / 2$ & $+1 / 2$ \\
\hline 23 & $121 / 4$ & Hybritech (USA) & $143 / 4$ & $13 \frac{1}{2}$ & $-11 / 4$ \\
\hline $161 / 4$ & $11 \frac{1}{2}$ & Molecular Genetics (USA) & $131 / 4$ & 14 & $+3 / 4$ \\
\hline $151 / 2$ & $101 / 4$ & Monoclonal Antibodies (USA) & 11 & $11 \frac{1}{4}$ & $+1 / 4$ \\
\hline $60 \% / 8$ & $451 / 2$ & Novo Industri A/S (Denmark) & $521 / 4$ & $48 \%$ & $-35 / 8$ \\
\hline $223 / 4$ & $16^{1 / 2}$ & Pharmacia (Sweden) & $163 / 4$ & $187 / 8$ & $+2 \frac{1}{8}$ \\
\hline
\end{tabular}

Closing prices are for the last Friday of the month. For over-the-counter stocks, bid price is quoted; for stocks on the American and New York exchanges, the transaction price. Nature's weighted index of biotechnology stocks stood at 169 on 30 March, compared with 163 a month earlier. Data from E.F. Hutton, Inc. 